\title{
Atrybuty żywności ekologicznej determinujące wybory konsumentów
}

\section{Wstęp}

Dynamicznie rozwijający się w ostatnich latach rynek ekologicznych produktów żywnościowych skutkuje koniecznością wdrażania instrumentów marketingu uwzględniającego specyfikę tego rynku. W ramach budowania przewagi konkurencyjnej oferty produktowej wprowadzana jest koncepcja atrybutów (cechy produktu, które spełniają potrzeby konsumentów) ekologicznego produktu żywnościowego.

Żywność ekologiczna charakteryzuje się cechami, które można odnieść do podziału na atrybuty indywidualne - osobiste (prywatne) i atrybuty społeczne - środowiskowe (publiczne). Do koszyka cech indywidualnych w żywności ekologicznej można zaliczyć smak, wartość zdrowotną, świeżość [Misra, Huang i Otto 1991] czy też wartości użytkowe produktu [Zanoli i Naspetti 2002]. Cechy produktu określane jako atrybuty indywidualne - prywatne są cenione z powodu przesłanek egoistycznych podyktowanych potrzebami konsumentów i ich rodzin. W przypadku atrybutów społecznych w żywności ekologicznej można wymienić aspekty ochrony środowiska czy respektowanie dobrostanu zwierząt w produkcji rolniczej. Uznane są one jako cechy nieużytkowe produktu, a dostrzeganie ich przez konsumentów jest związane z przesłankami altruistycznymi, jakie determinują ich zachowania. Te atrybuty powodują, że konieczne staje się postrzeganie żywności ekologicznej w szerszym aspekcie. Głównie w odniesieniu do stanu środowiska przyrodniczego i związków zachodzących pomiędzy metodami produkcyjnymi rolnictwa a środowiskiem przyrodniczym oraz pomiędzy środowiskiem a zdrowiem [Newerli-Guz i Śmiechowska 2004]. Właśnie środowiskowe aspekty żywności ekologicznej są coraz częściej dostrzegane przez konsumentów, co może wynikać z poziomu świadomości ekologicznej ba- 
danych, zwiększonej promocji zdrowia, marketingu społecznego realizowanego przez przedsiębiorstwa, zachowań obywatelskich konsumentów i producentów.

W innym ujęciu cechy produktu żywnościowego mogą zostać skategoryzowane $\mathrm{w}$ trzech klasach określane jako atrybuty sensoryczne, instrumentalne lub symboliczne, które są lokalizowane w określonych warstwach produktu (wewnętrznej i zewnętrznej) [Wierenga 1983].

Wyodrębnione w klasyfikacji sensoryczne walory produktu żywnościowego odnoszone są do fizycznych (sensorycznych) aspektów produktu takich, jak: smak, zapach, barwa, wygląd [Grzybowska-Brzezińska 2013a]. Atrybuty funkcjonalne to cechy produktu żywnościowego, które zaspokajają potrzeby konsumenta w zakresie realizacji procesów fizjologicznych, np. dostarczają energii, pomagają budować i utrzymywać różne komórki i organy ciała. Skład, zawartość specyficznych komponentów odżywczych (np. węglowodanów, białek, witamin), typy składników, obecność lub nieobecność dodatków mogą być sklasyfikowane jako atrybuty funkcjonalne. Aspekty produktu związane z jego użyciem, np. wielkość opakowania, łatwość przygotowania, metoda konserwacji mogą również zostać sklasyfikowane jako atrybuty funkcjonalne [Grzybowska-Brzezińska 2013a; Wierenga 1983]. Konsumpcja produktu żywnościowego może także eksponować motywy prestiżowe (próba kupowania produktów, które są w zgodzie $\mathrm{z}$ „koncepcją siebie” konsumenta) lub też może spełniać funkcję informacyjną (konsumpcja na pokaz). Symboliczne funkcje produktu są specyficzne i będą zależne od kultury społecznej, subkultury lub klasy społecznej. System tworzenia atrybutów prestiżowych jest zawiązany z pozycją marki produktu, producenta i sposobem komunikacji firmy z segmentem klientów. Cena produktu oraz miejsce, w którym dany produkt jest dostępny przyczyniają się do budowania prestiżowej wartości produktu [Lin 2002; Miyazaki, Grewal i Goodstein 2005].

Atrybuty żywności ekologicznej mogą być trudne do sprawdzenia przez konsumentów, którzy wykorzystują głównie ocenę organoleptyczną. Ważnym jednak jest fakt, że większość konsumentów kupuje produkty ekologiczne z powodu przekonania, że te produkty mają wyjątkowe (a w niektórych przypadkach lepsze) walory w porównaniu $\mathrm{z}$ alternatywami produkowanymi konwencjonalnie. W dyskusji dotyczącej żywności ekologicznej bardzo często podejmowany jest problem, czy produkty żywnościowe tej kategorii są lepsze od konwencjonalnie wyprodukowanych alternatyw, a jeżeli tak, to pod względem jakich cech? Wyniki badań w tym zakresie są bardzo zróżnicowane. W niektórych badaniach oceniano, czy istnieją różnice między żywnością ekologiczną i konwencjonalną z punktu widzenia tak producenta (czyli strony podaży), jak i konsumenta (czyli strony popytu). Dociekania badaczy z zakresu uwarunkowań strony podaży zwykle koncentrują się na wydajności, cenie producenta i porównaniach rentowności. Badania dotyczące determinant popytu weryfikowały różnice pod względem 
cech biofizycznych i chemicznych, jak również preferencji konsumentów i cen (detalicznych). Porównując żywność ekologiczną i wyprodukowaną konwencjonalnie w zakresie technologicznych atrybutów, wyniki badań wskazują, że wygląd jest często mniej ważny w decyzjach wyborów wśród regularnych konsumentów produktów ekologicznych, a w wyborach żywności konwencjonalnej jest jedną z znaczących kryteriów wyboru [Goldman i Clancy 1991]. Smak (tj. wrażenia smakowe), świeżość i okres trwałości produktu to inne cechy, które klienci biorą pod uwage przy swoich decyzjach zakupowych i są one cenione przez konsumentów zdecydowanie mocniej w wyborach żywności ekologicznej [Jolly i Norris 1991; Grzybowska-Brzezińska 2011, 2013b]. Po analizie wyników badań dotyczących poziomu wartości odżywczej produktów ekologicznych można wskazać na brak jednoznacznej opinii autorów co do jej znaczącej różnicy w przypadku żywności ekologicznej i konwencjonalnej. Konsumenci zdecydowanie deklaruja, że cenią żywność ekologiczną ze względu na większą wartość odżywczą tych produktów w porównaniu do żywności konwencjonalnej [Bourn i Prescott 2002]. W niektórych badaniach wskazano, że produkty ekologiczne mają niższą zawartość azotanów, wyższą zawartość suchej masy i minerałów $\mathrm{w}$ porównaniu z wyhodowanymi konwencjonalnie alternatywami [Letourneau, Drinkwater, Shennan 1996]. Można wskazać również różnice poglądów co do zawartości witaminy $\mathrm{C} \mathrm{w}$ produktach ekologicznych i konwencjonalnych. Podawano $\mathrm{w}$ jednych badaniach wyższą zawartość witaminy $\mathrm{C}$ w żywności ekologicznej, w innych stwierdzano wyższy poziom witaminy $\mathrm{C}$ w konwencjonalnych produktach żywnościowych, a różnice w wynikach przypisywano częściowo takim czynnikom jak dojrzałość przy zbiorze i warunki składowania [Bourn i Prescott 2002].

Zachowania konsumentów na rynku żywności ekologicznej należy rozpatrywać również przez pryzmat ich świadomości i poziomu wiedzy w zakresie specyficznych cech żywności ekologicznej. Zachowania rynkowe klienta obywatelskiego obejmują dokonywanie świadomych wyborów produktów o walorach społecznych m.in. przyjaznych środowisku. Wiedza i świadomość mają bezpośrednie i pośrednie skutki kształtowania postaw konsumentów wobec towarów i decydują o skłonności do płacenia premii cenowej w przypadku produktów o cechach społecznych. Produkty ekologiczne są tymi, wobec których podczas procesów zakupu konsumenci wykazują duży czynnik zaufania w zakresie ich technologii produkcji (w przeciwieństwie do producentów, którzy wiedzą, że ich produkty są ekologiczne). Konsumenci nie mają możliwości sprawdzenia w miejscu zakupu i również poza nim, czy produkt został wytworzony przy użyciu metod ekologicznych czy konwencjonalnych. Identyfikacja i weryfikacja technologii wytwarzania produktów żywności ekologicznej przez konsumentów może być możliwa jedynie po uzyskaniu przez nich wiarygodnej informacji, 
a może to być logo firmy produkującej, certyfikującej czy skład produktu [Giannakas 2002]. Świadomość społeczeństwa i wiedza w zakresie cech produktów ekologicznych, zaufanie do marki, miejsca produkcji mają decydujące znaczenie przy decyzjach rynkowych konsumenta [Grzybowska-Brzezińska i Rudzewicz 2015].

Celem podjętych badań była próba identyfikacji walorów żywności ekologicznej w ujęciu atrybutów technologicznych i rynkowych, określenie determinant kształtujących zachowania rynkowe nabywców tego rodzaju żywności w poszczególnych okresach realizowanych badań.

\section{Materiały i metody badań}

Przedmiotem badań była żywność ekologiczna rozumiana, jako żywność mająca polskie lub europejskie certyfikaty żywności ekologicznej i rolnictwa ekologicznego.

Badania realizowano w wybranych miastach północno-wschodniej Polski w latach 2005, 2010 i 2013, w okresie wiosennym marzec - kwiecień, zachowując ten termin $\mathrm{w}$ poszczególnych okresach badań. W badaniach wykorzystano metodę ankietową, a jako metodę kontaktowania się z respondentami wywiad bezpośredni, dane gromadzono na podstawie ustrukturyzowanego kwestionariusza [Mazurek-Łopacińska 1998]. W budowie narzędzi badawczych zastosowano m.in. skale nominalne, porządkowe oraz skalę Likerta. Dobór próby był nielosowy, badania realizowano na próbie uznaniowej, celowej (byli dobierani wyłącznie konsumenci żywności ekologicznej), również w każdym z okresów badań uwzględniano celowy dobór elementów populacji w zakresie grup wiekowych respondentów i ich wykształcenia. W 2005 roku analizowano 825 osób, badania realizowane w 2010 roku to deklaracje 971 przedstawicieli gospodarstw domowych, a w 2013 roku - 1205 wywiadów, w tym około 64\% stanowili mieszkańcy województwa warmińsko-mazurskiego. W każdym z kolejnych okresów badań liczba świadomych respondentów wzrastała, również zwiększał się segment regularnych konsumentów żywności ekologicznej. Najliczniejszą grupą wśród ankietowanych były osoby z przedziale wiekowym 21-50 lat oraz z wykształceniem średnim i wyższym. Wśród badanej populacji dominowały rodziny $\mathrm{z}$ jednym i dwójką dzieci do 6. roku życia, głównie mieszkańcy miast. 


\section{Wyniki badań i dyskusja}

\section{Percepcja atrybutów technologicznych i rynkowych żywności ekologicznej w wyborach badanych konsumentów}

Wyniki badań dotyczące świadomości i wiedzy konsumentów co do cech żywności ekologicznej wskazują, że chociaż istnieje na całym świecie ogólna świadomość konsumentów w zakresie zasad produkcji żywności ekologicznej, konsumenci (czasami w obrębie tego samego kraju) rozbieżnie interpretują określenie „ekologiczny”. Wielu konsumentów żywności ekologicznej rozpoznaje produkty ekologiczne na podstawie dołączonych ekologicznych oznakowań, logo i wskazują je jako identyfikatory produktu ekologicznego. Atrybuty sensoryczne i bezpieczeństwa żywności wpływały zdecydowanie na wybory konsumentów żywności ekologicznej [Bourn i Prescott 2002], również atrakcyjny wygląd, wygoda użytkowania i zakupu, to ważne determinanty wyboru produktów wytwarzanych naturalnie. W literaturze przy opisie klasyfikacji atrybutów żywności ekologicznej uwzględnia się dwie kategorie atrybutów technologicznych i rynkowych. W ramach kategorii atrybutów technologicznych wskazano cechy sensoryczne produktów, technologie wytwarzania, agrotechnikę, stosowanie dodatków do produkcji i przetwórstwa, sposób pakowania, skład. Atrybuty rynkowe to miejsce zakupu (dostępność), poziom ceny, ekspozycja w miejscu sprzedaży, zaufanie do marki, przyjazność dla środowiska czy działania promocyjne i reklamowe producentów [Grzybowska-Brzezińska 2013a]. Uwzględniając w realizowanych badaniach akceptację wybranych cech żywności ekologicznej, pytano o ocenę poszczególnych atrybutów tej żywności. Respondenci oceniali (od 1 - zupełnie nieważne do 5 - bardzo ważne) poszczególne cechy żywności ekologicznej, które sklasyfikowano jako atrybuty technologiczne i rynkowe. W tabeli 1 zaprezentowano strukturę wskazań ocen 5 - bardzo ważne w przypadku każdej cechy, w poszczególnych latach realizowanych badań.

Jako walory technologiczne żywności ekologicznej w badaniach uznano fakt, że są to produkty bez konserwantów, mają niski stopień przetworzenia, naturalny smak i wygląd, są wytwarzane bez nawozów sztucznych i środków ochrony roślin oraz zwierzęta żywione są naturalnymi paszami. W zakresie atrybutów rynkowych respondenci oceniali znaczenie takich cech jak mniejsza trwałość, aspekt wytwarzania żywności ekologicznej w czystym środowisku, fakt, że produkcja tej żywności nie zanieczyszcza środowiska czy była dostępna w hiper- $\mathrm{i}$ supermarketach.

Jako walory technologiczne respondenci uznali fakt, że są to produkty bez konserwantów i był to bardzo ważny atrybut w przypadku 73\% w 2013 roku, przy 52\% - w 2005 roku. Z kolei niski stopień przetworzenia już tylko w przy- 
Tabela 1

Atrybuty technologiczne i rynkowe żywności ekologicznej w opinii badanych respondentów [\%]

\begin{tabular}{|l|c|c|c|}
\hline \multirow{2}{*}{ Atrybuty } & 2005 & 2010 & 2013 \\
\cline { 2 - 4 } & \multicolumn{3}{|c|}{ Deklaracje [\%] } \\
\hline \multicolumn{2}{|c|}{ Technologiczne } \\
\hline Produkty bez konserwantów & 52 & 66 & 73 \\
\hline Niski stopień przetworzenia & 48 & 37 & 30 \\
\hline Naturalny smak & 56 & 53 & 67 \\
\hline Naturalny wygląd & 15 & 17 & 45 \\
\hline Wytwarzana bez nawozów sztucznych & 49 & 46 & 56 \\
\hline Bez środków ochrony roślin & 56 & 41 & 68 \\
\hline $\begin{array}{l}\text { Zwierzęta żywione sa naturalnymi paszami } \\
\text { (bez dodatku hormonów i antybiotyków) }\end{array}$ & 39 & 32 & 57 \\
\hline \multicolumn{1}{|c|}{ Rynkowe } & & 19 \\
\hline Mniejsza trwałość & 45 & 25 & 29 \\
\hline Wytwarzana w czystym środowisku & 41 & 43 & 79 \\
\hline Walory zdrowotne & 75 & 78 & 45 \\
\hline $\begin{array}{l}\text { Jej wytwarzanie nie zanieczyszcza } \\
\text { środowiska }\end{array}$ & 22 & 34 & 48 \\
\hline $\begin{array}{l}\text { Dostępna w hipermarketach } \\
\text { i supermarketach }\end{array}$ & 15 & 25 & 56 \\
\hline Szeroki asortyment & 8 & 11 & 25 \\
\hline Wysoka cena & 69 & 56 & 67 \\
\hline $\begin{array}{l}\text { Na opakowaniu jest logo producenta } \\
\text { żywności ekologicznej }\end{array}$ & 67 & 78 \\
\hline Wygoda przygotowania & 23 & 34 & \\
\hline
\end{tabular}

Źródło: Badania własne.

padku 30\% badanych w 2013 roku był bardzo ważnym atrybutem, a w 2005 ok. $50 \%$ respondentów wskazywało tę cechę jako bardzo ważną i determinującą zakupy. Naturalny smak był docenianym i bardzo ważnym atrybutem w wyborach konsumentów w każdym z okresów badań, a w 2013 roku ok. 70\% wskazało jego bardzo duże znaczenie determinujące konsumpcję. Wśród respondentów badanych w 2013 roku doceniany był naturalny wygląd tej żywności, co w latach wcześniejszych nie było tak istotnym atrybutem tych produktów. Wrażliwość konsumentów z zakresu sposobu żywienia zwierząt i wpływu tego zjawiska na walory żywności również zwiększyła się w poszczególnych okresach badań, a około $60 \%$ badanych w 2013 roku wskazało na bardzo duże znaczenie tego aspektu w wyborach żywności ekologicznej. 
Oceniając atrybuty rynkowe, badani wskazali walory zdrowotne żywności ekologicznej i jako bardzo istotny czynnik preferencji w zakresie tego rodzaju żywności wskazało ok. $80 \%$ badanych. Ważny był również system oznaczeń tej żywności, a wysoka cena ograniczeniem, tak deklarowało ponad $60 \%$ badanych niezależnie od okresu badań. Mniej znacząca w wyborach konsumentów żywności ekologicznej była niższa trwałość tej żywności i wytwarzanie jej w czystym środowisku. Z kolei szeroki asortyment, wygoda przygotowania posiłków i użytkowania tych produktów były oczekiwaniem deklarowanym przez badanych konsumentów żywności ekologicznej.

Identyfikując oczekiwania nabywców w zakresie żywności ekologicznej, badanych respondentów pytano o główne cechy produktów wpływające na wybór żywności ekologicznej. W tej klasyfikacji oceniano znacznie atrybutów sensorycznych (barwa, zapach), funkcjonalnych (skład, data przydatności do spożycia, metody produkcji i przetwórstwa) i prestiżowych (logo producenta, kraj/region pochodzenia, miejsce nabywania, cena) (tabele 2 i 3) w relacji do istotności poszczególnych cech $\mathrm{w}$ decyzjach zakupu (prawdopodobieństwie zakupu).

Głównymi atrybutami, jakimi kierowali się konsumenci przy zakupie żywności ekologicznej, były przede wszystkim atrybuty funkcjonalne, a ich identyfikatorami był skład (67\%), metody produkcji i przetwórstwa (69\%).

W przypadku atrybutów sensorycznych wygląd tej żywności wskazujący na tradycyjną produkcję był ważnym kryterium wyboru ocenianej żywności.

\section{Tabela 2}

Atrybuty sensoryczne, funkcjonalne i prestiżowe żywności ekologicznej w opinii badanych [\%]

\begin{tabular}{|l|c|c|c|}
\hline \multicolumn{1}{|c|}{ Kryteria wyboru } & 2005 & 2010 & 2013 \\
\hline \multicolumn{4}{|c|}{ Atrybuty sensoryczne } \\
\hline Wygląd (barwa, konsystencja) & 78 & 53 & 62 \\
\hline Zapach & 46 & 35 & 45 \\
\hline \multicolumn{4}{|c|}{ Atrybuty funkcjonalne } \\
\hline Skład & 34 & 49 & 67 \\
\hline Data ważności do spożycia & 24 & 47 & 52 \\
\hline Metody produkcji i przetwórstwa & 89 & 78 & 69 \\
\hline \multicolumn{4}{|c|}{ Atrybuty prestiżowe } \\
\hline Logo producenta & 34 & 47 & 58 \\
\hline Kraj/region pochodzenia & 56 & 44 & 49 \\
\hline Miejsce nabywania & 7 & 9 & 45 \\
\hline Cena & 89 & 78 & 56 \\
\hline
\end{tabular}

Źródło: Badania własne. 
Tabela 3

Parametry liniowych modeli regresji wielorakiej między cechami żywności ekologicznej a prawdopodobieństwem wyboru tych produktów w poszczególnych okresach badań

\begin{tabular}{|c|c|c|c|c|c|c|}
\hline \multirow[b]{2}{*}{$\begin{array}{l}\text { Kryteria wyboru } \\
\text { decydujace } \\
\text { o zakupie }\end{array}$} & \multicolumn{2}{|c|}{2005} & \multicolumn{2}{|c|}{2010} & \multicolumn{2}{|c|}{2013} \\
\hline & $\begin{array}{c}\text { relatywna } \\
\text { ważność } \\
{[\%]}\end{array}$ & $\begin{array}{l}\text { współ- } \\
\text { czynnik }\end{array}$ & $\begin{array}{c}\text { relatywna } \\
\text { ważność } \\
{[\%]}\end{array}$ & $\begin{array}{l}\text { współ- } \\
\text { czynnik }\end{array}$ & $\begin{array}{c}\text { relatywna } \\
\text { ważność } \\
{[\%]}\end{array}$ & $\begin{array}{l}\text { współ- } \\
\text { czynnik }\end{array}$ \\
\hline \multicolumn{7}{|c|}{ Atrybuty sensoryczne - technologiczne } \\
\hline $\begin{array}{l}\text { Wygląd (barwa, } \\
\text { konsystencja) }\end{array}$ & 67,3 & $2,843^{* *}$ & 65,5 & $0,531^{* *}$ & 59,5 & $0,724^{* * *}$ \\
\hline Zapach & 32,7 & $0,532^{* *}$ & 34,5 & $0,313^{* *}$ & 40,5 & $0,256^{\star *}$ \\
\hline- & \multicolumn{2}{|c|}{$\mathrm{R}^{2}=0,6578$} & \multicolumn{2}{|c|}{$\mathrm{R}^{2}=0,7458$} & \multicolumn{2}{|c|}{$\mathrm{R}^{2}=0,7545$} \\
\hline \multicolumn{7}{|c|}{ Atrybuty funkcjonalne - technologiczne } \\
\hline Skład & 29,5 & $0,678^{* *}$ & 29,5 & $0,756^{\star *}$ & 36,2 & $1,956^{* *}$ \\
\hline $\begin{array}{l}\text { Data ważności } \\
\text { do spożycia }\end{array}$ & 21,0 & $-0,632$ & 23,6 & $-1,765^{*}$ & 29,9 & $-0,786^{* * *}$ \\
\hline $\begin{array}{l}\text { Metody produkcji } \\
\text { i przetwórstwa }\end{array}$ & 49,5 & $2,567^{*}$ & 46,9 & $2,453^{* *}$ & 33,9 & $1,456^{* * *}$ \\
\hline- & \multicolumn{2}{|c|}{$R^{2}=0,6321$} & \multicolumn{2}{|c|}{$\mathrm{R}^{2}=0,7523$} & \multicolumn{2}{|c|}{$R^{2}=0,6826$} \\
\hline \multicolumn{7}{|c|}{ Atrybuty prestiżowe - rynkowe } \\
\hline Logo producenta & 29,2 & $0,302^{* \star}$ & 24,3 & $0,456^{\star *}$ & 30,9 & $0,564^{* *}$ \\
\hline $\begin{array}{l}\text { Kraj/region } \\
\text { pochodzenia }\end{array}$ & 16,3 & $0,187^{\star * *}$ & 21,7 & $0,356^{*}$ & 25,9 & $0,321^{* *}$ \\
\hline $\begin{array}{l}\text { Miejsce } \\
\text { nabywania }\end{array}$ & 15 & $-0,125^{\star}$ & 11,7 & $-0,231^{*}$ & 17,3 & $-0,167^{* *}$ \\
\hline Cena & 39,5 & $-0,445^{\star *}$ & 42,3 & $-0,657^{*}$ & 25,9 & $-0,234^{* *}$ \\
\hline- & \multicolumn{2}{|c|}{$\mathrm{R}^{2}=0,5327$} & \multicolumn{2}{|c|}{$\mathrm{R}^{2}=0,656$} & \multicolumn{2}{|c|}{$R^{2}=0,5932$} \\
\hline
\end{tabular}

Uwagi: ${ }^{*},{ }^{* *},{ }^{* * *}$ - istotność statystyczna na poziomie wynoszącym odpowiednio: $\alpha \leq 0,1$, $\alpha \leq 0,05, \alpha \leq 0,01$.

Źródło: Badania własne.

W przypadku atrybutów prestiżowych zdecydowanie ważne w opinii badanych w 2013 roku było logo producenta i poziom ceny. W analizie poszczególnych okresów badań zdecydowanie w 2013 roku było ważne miejsce nabywania żywności ekologicznej tak deklarowało ok. 45\% respondentów, a w 2005 roku zaledwie 7\% konsumentów wskazywało ten atrybut jako ważny.

Analiza regresji liniowej, w której modelowano wpływ cech żywności ekologicznej na prawdopodobieństwo zakupu wskazuje, że współczynniki kierunkowe przyjmują wartości dodatnie w przypadku atrybutów sensorycznych w każdym okresie badań. Wysoką relatywną ważność obserwowano w przypadku wyglądu w każdym z okresów badań a w przypadku zmiennej zapach najwyż- 
sza relatywna ważność występuje w deklaracjach konsumentów w 2013 roku. Analiza regresji liniowej, w której modelowano wpływ zmiennych z zakresu atrybutów funkcjonalnych na prawdopodobieństwo zakupu żywności ekologicznej, wskazuje, że w przypadku składu i metod produkcji i przetwórstwa współczynniki kierunkowe przyjmują wartości dodatnie we wszystkich okresach badań, a w przypadku daty ważności do spożycia ujemne. Skład, metody produkcji i przetwórstwa były znaczące $w$ decyzjach wyboru żywności ekologicznej w każdym z okresów badań z relatywną ważnością na poziomie ok. $30 \% \mathrm{w}$ przypadku składu i ok. $40 \%$ w przypadku metod produkcji i przetwórstwa. W przypadku atrybutów prestiżowych analiza regresji liniowej, w której modelowano wpływ logo producenta, regionu produkcji, miejsca nabywania i ceny na prawdopodobieństwo zakupu, wskazuje, że współczynniki kierunkowe przyjmują wartości dodatnie w przypadku logo producenta i miejsca produkcji, natomiast miejsce sprzedaży i cena przyjmują ujemne wartości wskaźników.

Współczynniki kierunkowe w przypadku atrybutów technologicznych i rynkowych są statystycznie istotne $(\alpha \leq 0,1)$.

W decyzjach zakupu żywości ekologicznej wzrasta znaczenie zaufania konsumentów do producentów i sprzedawców tej żywności, co przy decyzjach rutynowych, jakimi są wybory żywności, jest zrozumiałym zjawiskiem. Schemat zakupu żywności jest skrócony i ocena atrybutów alternatyw produktów jest ograniczona, dlatego czytelna etykieta i ekspozycja produktu w miejscu sprzedaży będą decydowały o wyborach produktów. Skład czy inne walory technologiczne są atrybutami, które ocenia klient na podstawie wiarygodnej informacji na opakowaniu, również na podstawie zaufania do producenta. Dlatego ważnym zjawiskiem w kreowaniu identyfikatorów żywności ekologicznej jest pozycjonowanie marek o dużym zaufaniu, budowanie i podtrzymywanie tego zaufania wśród segmentów rynku docelowego.

\section{Wnioski}

Rynek produktów ekologicznych jest w Polsce wciąż jeszcze rozwijającym się, nieustabilizowanym, na którym należy szeroko i umiejętnie wykorzystać różne instrumenty marketingowe. Najważniejsza jednak jest właściwa segmentacja konsumentów oraz zróżnicowanie działań marketingowych w odniesieniu do różnych grup nabywców - o różnym poziomie świadomości ekologicznej. W tym kontekście niezwykle ważna staje się wiedza na temat zachowań konsumentów, motywów zakupu oraz preferowanych form sprzedaży tej żywności. Mimo iż analiza empiryczna wykonana na potrzeby niniejszego opracowania nie ma znamion reprezentatywności (dobór próby badawczej miał charakter ce- 
lowy) i z naukowego punktu widzenia nie należy dokonywać na jej podstawie wnioskowania, to jednak uzyskane rezultaty mogą być wykorzystane jako źródło informacji o zarysowanych zachowaniach konsumenckich na rynku żywności ekologicznej.

Z przeprowadzonych badań wynika, że w opinii badanych respondentów głównym czynnikiem kształtującym jakość żywności ekologicznej są nadal wysokie walory zdrowotne oraz jej naturalność i odpowiednia wartość odżywcza. Zdecydowana większość badanych identyfikowała żywność pochodzącą z rolnictwa ekologicznego z żywnością produkowaną z dużym ograniczeniem stosowania chemii rolnej, w regionie o niewielkim skażeniu środowiska. Konsumenci cenili fakt, iż żywność ekologiczna w porównaniu z żywnością konwencjonalną zawiera mniej konserwantów oraz charakteryzuje się dobrym, naturalnym smakiem i wyglądem. Badani respondenci przy zakupie produktów pochodzących $\mathrm{z}$ rolnictwa ekologicznego w głównej mierze kierowali się przekonaniem, że tego rodzaju produkty są bezpieczne dla zdrowia oraz że ich produkcja i przetwarzanie nie ma negatywnego wpływu na środowisko.

W budowaniu oferty asortymentu żywności ekologicznej należy rozważyć atrybuty technologiczne, głównie cechy organoleptyczne i sensoryczne, tj. wygląd, zapach, również metody wytwarzania i przetwórstwa, skład tej żywności. W przygotowaniu atrybutów rynkowych ważne jest logo producenta, szerokość asortymentu oraz walory zdrowotne. Bardzo ważne w zachowaniach nabywców są technologiczne aspekty wytwarzania tej żywności i jej naturalny zapach, smak i wygląd. Rynkowe atrybuty, jakie powinny być tworzone w tej kategorii żywności, to szeroki asortyment, zwiększenie dostępności tej żywności, zweryfikowanie aspektów jej zdrowotności oraz zwiększenie wiarygodności informacji w zakresie składu tych produktów.

\section{Literatura}

BOURN D. AND PRESCOTT J., 2002: A comparison of the nutritional value, sensory qualities and food safety of organically and conventionally produced foods, Critical Reviews in Food Science and Nutrition 42 (1), 1-34.

GIANNAKAS K., 2002: Information asymmetries and consumption decisions in organic food product markets, Canadian Journal of Agricultural Economics 50, 35-50.

GOLDMAN B.J. and CLANCY K.L., 1991: A survey of organic produce purchases and related attitudes of food cooperative shoppers, American Journal of Alternative Agriculture 6 (2), 89-96.

GRZYBOWSKA-BRZEZIŃSKA M., RUDZEWICZ A., 2015: Environmental management systems in food processing and production as a source of product value for the customer on the organic food market, International Journal of Business Performance Management 16 (Nos. 2/3), 314 . 
GRZYBOWSKA-BRZEZIŃSKA M., 2011: Świadomość ekologiczna konsumentów a ich zachowania na rynku żywności, Studia i Materiały Polskiego Stowarzyszenia Zarządzania Wiedzą (51), 242-253.

GRZYBOWSKA-BRZEZIŃSKA M., 2013a: Preferencje konsumentów w ksztaltowaniu atrybutów produktu żywnościowego, Wyd. Uniwersytetu Warmińsko-Mazurskiego w Olsztynie, Olsztyn.

GRZYBOWSKA-BRZEZIŃSKA M., 2013b: Wpływ instrumentów marketingu ekologicznego na zachowania konsumentów na rynku produktów spożywczych, Zeszyty Naukowe Uniwersytetu Szczecińskiego nr 775 Problemy Zarządzania, Finansów i Marketingu (30), 47-58.

JOLLY D.A., NORRIS K., 1991: Marketing prospects for organic and pesticide-free produce. American Journal of Alternative Agriculture 6 (4),174-179.

LETOURNEAU D.K., DRINKWATER L.E., SHENNAN C., 1996: Effects of soil management on crop nitrogen and insect damage in organic versus conventional tomato fields, Agriculture, Ecosystems and Environment, 57,179-187.

LIN C., 2002: Attribute-consequence-value linkages: A new technique for understanding customer's product knowledge, Journal of Targeting Measurement and Analysis for marketing 10 (4), 339-352.

MAZUREK-ŁOPACIŃSKA K., 1998: Badania marketingowe. Podstawowe metody i obszary zastosowań. Wyd. Akademii Ekonomicznej im. Oskara Langego we Wrocławiu, Wrocław.

MISRA S., HUANG C.L., OTTO S.L., 1991: Consumer Willingness to Pay for Pesticide-free Fresh Produce, Western Journal of Agricultural Economics 16 (2), 57-87.

MIYAZAKI A.D., GREWAL D., GOODSTEIN R.C., 2005: The effect of multiple extrinsic cues on quality perceptions: A matter of consistency, Journal of Consumer Research 32 (1), 146-153.

NEWERLI-GUZ J., ŚMIECHOWSKA M., 2004, Walory żywności ekologicznej w opinii konsumentów, Bromatologia i chemia toksykologiczna, SUPLEMENT, 137

ZANOLI R., NASPETTI S., 2002: Consumer Motivations in the Purchase of Organic Food, British Food Journal 104 (8/9), 37-39.

\section{Abstrakt}

W artykule podjęto problematykę zachowań konsumentów na rynku żywności ekologicznej. Wskazano rodzaje cech ekologicznych produktów żywnościowych, które są walorami tej kategorii żywności. Celem podjętych rozważań była prezentacja problematyki percepcji konsumentów w zakresie walorów żywności ekologicznej i wskazanie tych cech, które decydują o jej wyborze i konsumpcji. W badaniach uwzględniono oceny konsumentów odnoszące się do walorów żywności ekologicznej, a wśród nich uwzględniono kategorie atrybutów technologicznych i rynkowych. W artykule przedstawiono wyniki sondaży, które przeprowadzano w latach 2005, 2010 i 2013 wśród mieszkańców północno-wschodniej Polski. Głównymi atrybutami technologicznymi żywności 
ekologicznej wskazanymi przez badanych była wartość odżywcza oraz ceniony przez respondentów system produkcji tej żywności, zapewniający ograniczenia w użyciu chemii rolnej. Badani konsumenci w każdym z okresów badań cenili walory sensoryczne żywności ekologicznej i jako główną cechę wskazali naturalny smak. Rynkowe atrybuty żywności ekologicznej, jakie zidentyfikowano w badaniach, to walory zdrowotne, miejsce zakupu, logo producenta i cena. W atrybutach żywności ekologicznej eksponowane były również cechy społeczne tych produktów.

Słowa kluczowe: żywność ekologiczna, atrybuty żywności ekologicznej, zachowania konsumenta

\section{Organic food attributes that determine consumer choices}

\section{Abstract}

The aim of the research was to identify factors influencing consumer perception of organic food quality. The research concerned the consumers' assessment of certain attributes (technological and market ones) of organic food products. The surveys were carried out in 2005, 2010, and 2013 among the inhabitants of northeast Poland. The main technological attributes indicated by the respondents were the nutrition value of the food and highly valued way of its production, ensuring limited use of fertilizers, pesticides, and other chemicals. In all analyzed periods the respondents valued sensory features of organic food, especially its natural taste. Market attributes of organic food that were identified during the study are the following: health values, place of purchase, producer's logo, and price. Among the attributes of the organic products also their social features were presented.

Key words: organic food, consumer behaviors, the attributes of organic food 